\section{MIDWINTER MEETINGS}

(Contintued from Page 273)

Tuesday, January 9, 4:30-6:00 p.m. (University)

Wednesday, January 10, 8:00-9:30 a.m. (College)

ACRL JoInt CommiteEs

AAC-ACRL Committee on College Libraries

Friday, January 12, Luncheon, 12:00 noon

ACRL Publications

CHOICE Editorial Board

Monday, January 8, 4:30-6:00 p.m.

Tuesday, January 9, 2:00-4:00 p.m.

ACRL Monograph Series Editorial Board

Tuesday, January 9, Luncheon, 12:00 noon

ACRL Sections and Subsections

College Libraries Section

Committee on Non-Western Resources

Monday, January 8, 2:00-4:00 p.m.

Monday, January 8, 8:30-10:00 p.m.

Steering Committee

Tuesday, January 9, 4:30-6:00 p.m.

Junior College Libraries Section

Bibliography Committee

Wednesday, January 10, 4:30-6:00 p.m.

Executive Committee

Thursday, January 11, 10:00-12:00 noon

Thursday, January 11, 4:30-6:00 p.m.

Ad Hoc Committee on Instructional Materials Centers

Monday, January 8, 8:30-9:30 a.m.

Preconference Planning Committee

Monday, January 8, 8:30-10:00 p.m.

"Committee to Revise the JCLS Bylaws

Tuesday, January 9, 4:30-6:00 p.m.

* Special Projects Committee

Thursday, January 11, 8:30-9:30 a.m.

Subject Specialists Section

Executive Committee

Monday, January 8, 5:30-6:00 p.m.

Agriculture and Biological Sciences

Subsection

Executive Committee

Monday, January 8, Luncheon, 12:00 noon

Slavic and East European Subsection

Executive Committee

Monday, January 8, 8:30-10:00 p.m.

* Indicates meeting open to observers upon written request to the chairman.
University Libraries Section

Ad Hoc Committee on Academic Status

Monday, January 8, 10:00-12:00 noon

${ }^{*}$ Committee on Extension Library Service

Tuesday, January 9, 4:30-6:00 p.m.

Steering Committee

Wednesday, January 10, 8:00-9:30 a.m.

"Urban Universities Library Committee Wednesday, January 10, 2:00-4:00 p.m.

\section{COPYRIGHT TECHNOLOGY COMMISSION}

S. 2216, a bill to establish in the Library of Congress a National Commission on New Technological Uses of Copyrighted Works, was passed by the Senate and referred to the House Judiciary Committee on October 12. The purpose of the Commission is to study and compile data on the reproduction and use of copyrighted works of authorship (1) in automatic systems capable of storing, processing, retrieving, and transferring information. and (2) by various forms of machine reproduction. The Commission is directed to make recommendations to the President and the Congress concerning such changes as may be necessary to assure access to copyrighted works and to provide recognition of the rights of copyright owners.

The bill calls for a 23-man Commission under the chairmanship of the librarian of Congress and requires them to submit a preliminary report within one year after their first meeting and a final report within three years after the effective date of the Act. The report is to include recommendations and proposals for legislation and administrative action necessary to carry out its recommendations. In addition to the librarian of Congress, the Commission is to be composed of two members of the Senate; two members of the House of Representatives; seven members selected from authors and other copyright owners; seven members selected from users of copyrighted works; and four nongovernmental members selected from the general public.

The need for this study commission became apparent during Senate hearings on S. 597, the bill to generally revise the copyright law. It was decided that a thorough investigation of the possible copyright problems arising from various technological advances would cause several years' delay in enacting the general copyright revision bill. "Therefore, the establishment of some type of study commission appeared to be both necessary and desirable," according to the Senate Judiciary Committee Report on the bill (S. Rept. 640). 